European Journal of Logistics, Purchasing and Supply Chain Management

Vol.8 No.3, pp.50-73, August 2020

Published by ECRTD UK

ISSN 2054-0930 (Print), ISSN 2054-0949 (Online)

\title{
AN INVESTIGATION OF DETERMINANTS OF THE INSTITUTIONAL PROCUREMENT PERFORMANCE: A CASE OF THE AFRICAN DEVELOPMENT BANK IN COTE D'IVOIRE
}

\author{
Mr. Elvis Babila Nubea'a, \\ School of Business and Economics, Mount Kenya University-Thika, 08 BP 4134 Abidjan 08 \\ Email: babilachongwa@gmail.com
}

\begin{abstract}
Peter Wamalwa Barasa, PhD
School of Business and Economics, Mount Kenya University-Thika P.O BOX 42702- 80100, Mombasa

Kenya

Email: petbar2001us@yahoo.com
\end{abstract}

\begin{abstract}
Today's dynamics of business environment has placed both the private and public institutions in competition for best practices. It is now a necessity for organizations to provide their clients with cost effective solutions and better customer satisfaction with innovative ideas and methods. One most important approach to gain competitive advantage in a dynamic market environment is by adopting effective procurement practices which determine organizational performance. The purpose of the study was to examine the determinants of institutional procurement performance. Specific objectives of this research work was to find out the effect of staff competence on procurement performance at the African Development Bank; to ascertain the influences of organizational structure on procurement performance at the African Development Bank; establishing the contributions of quality management system on institutional procurement performance at the African Development Bank and finally to examine the influence of information communication technology (ICT) on institutional procurement performance at African Development Bank. The study adopted a descriptive research design. The target population consisted of one hundred and forty (140) procurement staff of the African Development Bank based in Abidjan. A purposive sampling technique was used to select forty two (42) participants involved in procurement practices in the Bank. Primary data was collected from self-administered questionnaire which was analyzed using SPSS Statistical Software Version 23. The research findings were presented in the form of tables and figures. Research finding shows that the independent variables staff competence, Organization structure, Quality management system and Information Technology significantly influence the institutional procurement performance, $F(4,34)=6.22, p=0.001, R 2=0.453$. The finding of this study indicated that procurement is both a driving force through competitive strategic selection and an important resource to achieving improved organizational performance. It is expected that if procurement practices are employed effectively, they will improve firm-customer relationship, preserve the environment, motivate and improve the coordination of staff. One limitation of the study was that the researcher was not allowed access to confidential procurement policy documents of the Bank.
\end{abstract}

KEY WORDS: institutional procurement performance, African Development Bank, Cote D'Ivoire, 
European Journal of Logistics, Purchasing and Supply Chain Management

\author{
Vol.8 No.3, pp.50-73, August 2020 \\ Published by ECRTD UK
}

ISSN 2054-0930 (Print), ISSN 2054-0949 (Online)

\title{
INTRODUCTION
}

The business environment has witness an expanding number of competitors both in local and global trades. Procurement therefore is a mechanism put in place by private and public organizations to acquire goods and services in other to meet various institutional needs. This mechanism is a crucial element at the heart of any functioning institution. Gompers, Ishii and Metrick (2013), states that procurement performance is important to an organization because its ability to perform financially is critical thus must be monitored at all times. This becomes very vital to the organization's financial health as most part of institutional income is dedicated to acquiring quality goods and services which if well administered will bring in more return. The absence of effective and comprehensive procurement policy will reduce the choice of suppliers and thus leads to higher price charges (Ondigi \& Muturi, 2015). Therefore, managers have the responsibility to put the acquired goods and services in the right productive direction which brings forth high quality output, elimination of waste and expanding to new markets and efficiently taking control of its supply chain. Chong and Ooi, (2008) acknowledged the above mentioned are pre-requisites for inventory reduction, best customer service and a low cost of production.

Globally, challenges facing different organization are numerous and unique depending on the socio- political, cultural and economic environment (Thai, 2010). Though institutional procurement challenges are different, they may be the same but at different levels when compared between countries. Public procurement globally is viewed as an avenue of wastage and corrupt practices. According to Chapman (2016), untrained personnel and poor procurement system creates leakages in the institutions financial system. An example in point was the loss of thousands of dollars in multiple cases involving in disposal of the United States government items. This is common with most countries as state officials of often face charges of misappropriation of funds. Procurement performance in the public institutions has attracted deep consideration worldwide. Owing to the usage of traditional procurement practices, organizations have continued to allow infamous purchase practices from non-preferred suppliers who prices are usually on the high side (Thumbi \& Mutiso 2018).

According to Thai (2010) adoption ofe-government procurement is likely to increase competition, transparency and accountability, efficiency and enables faster procurement decisions. Another challenge which is faced by international organizations is complying with public procurement practices at the global level. This is explained by the difficulties encountered by organizations in complying with national economic policies without breaching the trade agreements in the global economy such as those agreed upon by World Trade Organization (WTO). This therefore calls for a careful consideration to enable countries to take advantage of special provisions. Public healthcare sector in Australia, face critical challenges to compliance of public procurement which suffers from have lack of legislation, inadequate backing from the senior managers, little or no comprehension of procurement policy and collaboration with suppliers (Ahsan \& Rahman (2017).

According to Neuhaus, Schmitz and Umbeck (2015) most Northern American executives think that most company's struggles are to blame for loss in savings through poor procurement performance. Organizations in developed countries shows a far level of adoption and regulating procurement practices in public expenditure which have witnessed a quick gain in momentum and an extensive effect on performance and efficiency (Njoroge \& Ngugi, 2016). According to (Inozofu 2016) adept skills and training in procurement is an essential key to performance as most report states incompetency and legal framework as a major setback to procurement performance. Further, use of electronic processing in the procurement has been proven to 
improve the systems in countries such as Korea. In fact, Procurement Act has led to Korean institutions reducing their procurement cycle systems, improved efficiency, reduced procurement cost and enhanced compliance towards policy and standards (Chang, 2011).

Regional Public procurement practices have been a widely debated subject in the African continent and in the business hub of the Sub-Saharan Africa. The continent attracts a lot of interest from the developed world because of the development stage. McGinity (2014) observed that if the right procurement regulations are put in place,Africa countries will greatly harness the practices which will lead to higher performance of public expenditure leading to effective procurement performance and efficiency. Conversely, unregulated public institutions will increase the opportunity for frauds and embezzlement of billions of shilling from the public coffers (Ohkubo, 2012). In Ghana, the evaluation of procurement practices in public enterprises is done with reference to compliance of procurement regulations (Schapper, Veiga\& Gilbert, 2006). Public procurement Act 663 contains in detail all what is required and obliged for proper spending of public resources as enshrined in the legislation. (Osarfo-Marfo, 2003).

In Uganda, the creation of Public Procurement and Disposal of Assets Authority (PPDAA) in 2003 serves as a regulatory instrument which provide guidelines and regulations in public procurement of all public institutions in Uganda. Similarly, other countries like Tanzania and Kenya have also set out procurement regulatory Act which covers all procurement regulations on issues critical to procurement practices and performance. (Eyaa \&Oluka, 2011). In most third world countries, procurement reform is a vital and ongoing policy object. Kenya as an example has taken a positive direction in administrative changes that are being implemented which will positively serve both private and public institution by improving the livelihood of the citizens and provide sustainable good governance (Kempe, 2012).

Locally, there are multiple crises within the private and public sector which ranges from recruitment of qualified personnel and retaining them. How to develop new talents in form of creating training institutions that will enhance their skills to man the various procurement functions. As stated by Juma (2010) the entire procurement system in developing countries are suffering from corrupt practices which has greatly hindered procurement development capacity. The African Development Bank report (2018) on procurement policy provides a vital and comprehensive approach on lending framework which governs the investment operations. its procurement policy constitutes a pivotal role because it is the core of its fiduciary obligations.

In order to ensure efficiency in the massive procurement procedures, for instance, the Ivorian Ministry of Finance, instituted an integrated computer system for the public sector tender procedure called "System Integre de gestion des Merches Publics' (SIGMAP). Similar measures are also adopted by other governments in the region. It simply implies that there are yet to be identified, underlying circumstances acting against the proper functioning of procurement institutions. Accordingly, there are many issues raised in this research work that helps us measure the effect of procurement performance especially the African Development Bank, (AFDB) such as staff competence, organizational structure, quality management and the application of information technology. 
European Journal of Logistics, Purchasing and Supply Chain Management

Vol.8 No.3, pp.50-73, August 2020

Published by ECRTD UK

ISSN 2054-0930 (Print), ISSN 2054-0949 (Online)

\section{Specific Objectives of the Study}

i. To investigate the effect of staff competence on institutional procurement performance at the African Development Bank

ii. To find out the influence of organizational structure on institutional procurement performance at the African Development Bank.

iii. To investigate the contributions of quality management system on institutional procurement performance at the African Development Bank

iv. To ascertain the influence of information technology on institutional procurement performance at the African Development Bank.

\section{LITERATURE REVIEW}

The study adopted the following theories; Diffusion of Innovation theory; Network theory and Theory of Social System

\section{Conceptual Frame work}

This is a concept that is designed to demonstrate the link or relationship between the independent and the dependent variables. This is research work; the independent variables consist of staff competence, organizational structure, quality management and information technology. While the dependent variable is procurement performance, sub-classified into quality service and efficiency which transcends into customer satisfaction. The diagram below guided the study and also brought forth the interrelationship between the variables in the study.

As defined by Reichel and Ramey in 1978, the conceptual framework is seen as a set of ideas that spring from relevant fields of enquiry and put into a presentation. Maria Magher (2018) opines that it could be a graphical or a narrative way of presenting the research variables. Both the dependent and the independent variables have been well structured in the diagram below to illustrate the relationship that exist between staff competence, organizational structure, quality management system and information communication technology and procurement performance. 
European Journal of Logistics, Purchasing and Supply Chain Management

Vol.8 No.3, pp.50-73, August 2020

Published by ECRTD UK

ISSN 2054-0930 (Print), ISSN 2054-0949 (Online)

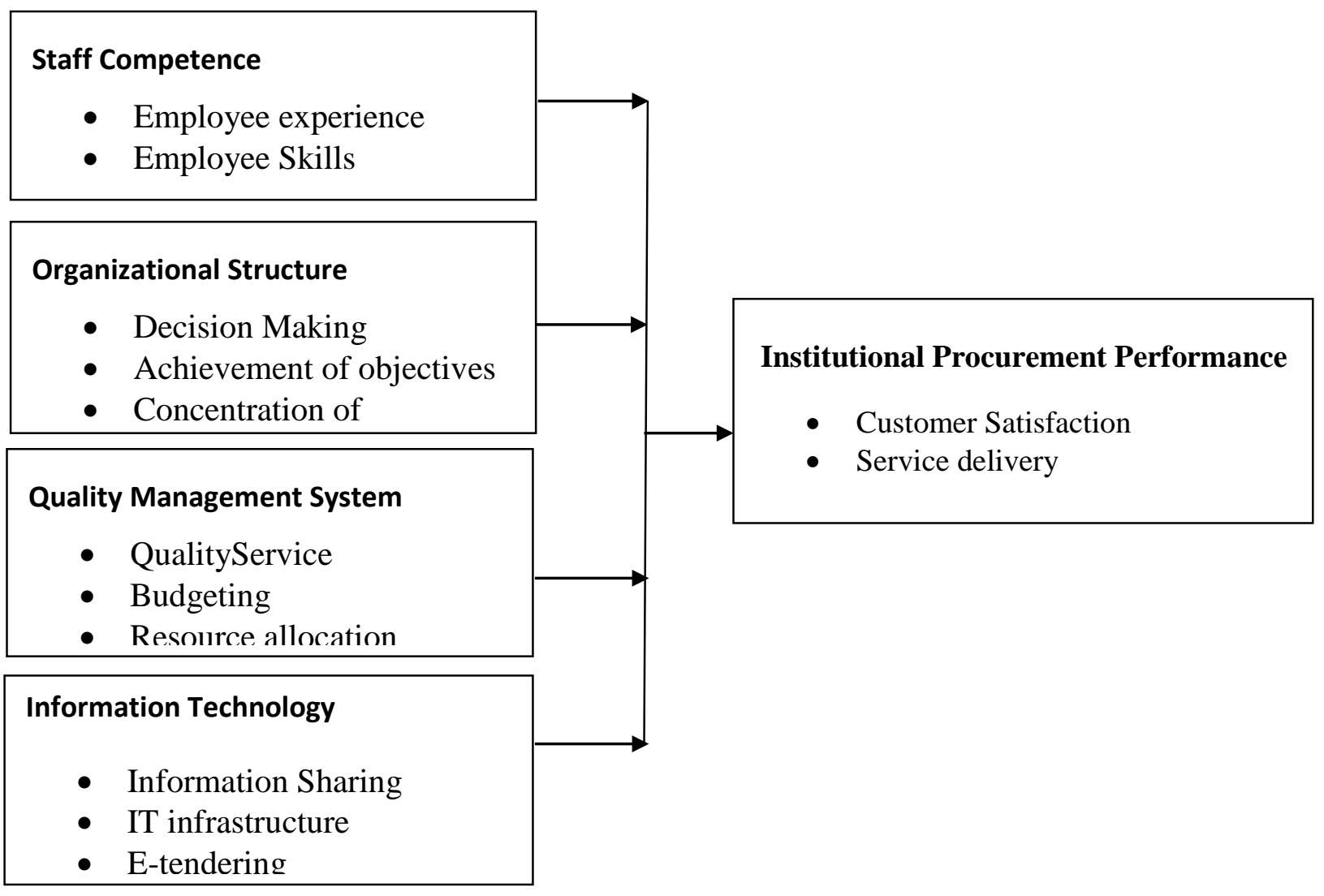

Influence of Staff Competence on institutional Procurement Performance.

Banda (2009), posits that most institutions are yet to have or do not have competent staff with the right knowhow to carry out or manage procurement practices requires the authorities to develop the right know-how in order to adopt best practices. Big projects require high financing in acquiring top management or senior level staff to handle them.

This in some cases raise company's budgets to exceeding levels or by substantial margins. There is therefore the need for most institutions with procuring functions to bring down cost for acquiring senior procurement staffs and put budget at reasonable levels. To maintain high standard and quality based performance, human resources have the responsibility to recruit technocrats in the field to carry out procurement functions. This will reinforce standards and build performance based workforce in the organization.

Budgets constrain could also be a limitation to the recruitment of competent procurement practitioners because there are few highly trained and competent professionals who will follow high pay packages. Public and private institutions are required to follow regulatory agencies for capacity reinforcement. Berger and Humphry (2007) states that professionals in the field of procurement with the right competencies deliver on time, drive down cost of production and bring out the real value for money. They also noted in the study that many procurement staffs are yet to be trained on procurement regulations and practices that enhanced efficiency and delivery, sustaining economic growth and effective performance which implies optimizing the 
European Journal of Logistics, Purchasing and Supply Chain Management

$$
\begin{array}{r}
\text { Vol.8 No.3, pp.50-73, August } 2020 \\
\text { Published by ECRTD UK }
\end{array}
$$

ISSN 2054-0930 (Print), ISSN 2054-0949 (Online)

output of all the staff in order to achieve the objectives and targets of the institutions. Accordingly, (Sultana 2012), suggest that constant skills and ICT upgrade leads to organizational change which is the corner stone for success of any organization. He therefore states that, training and persistent investment in Human capacity development leads to greater performance.

Common phenomenon in the system of education of most African state does not translate the theories taught into practical work required in executing procurement task. This therefore requires that specific responsibilities be given to staff with the technical know-how in the organization. Most procurement institution requires that staff undergo constant training to upgrade their competencies in the field of procurement. Given this assertion, Appiah (2010) explains the need for on the job training of staff which greatly influences organizational performance. He sees a very positive relationship between the available resources for staff training and the performance. Seleim (2007) added that competency boast staff selfconfidence and self-worth especially when they are efficient and this improve institutional performance.

Boyan (2003) indicated that, there is the need for procurement practitioners who handles supplies or any services to handle them efficiently to avoid waste and damages which will in turn reduce cost and maintain the profit margin of the organization. This protects the organization; keeps work to a minimum, and maintain the good reputation and relationships with its clients. He further stated that, procurement is about how things are done which could either lead to higher or lower cost depending on the level of competence of the staff.

\section{Influence of Organization Structure on institutional procurement performance}

As indicated by Hodgetts (1994), early classical theorists believed in the concept of a universal design theory, composed of a series of principles that could be used in organizing an enterprise. Some of the universal design theories as identified by Baridam (1999) include division of labor, unity of command, unity of management, span of control, scalar principles, and exception principle. Hodgetts (op cit) posits that in procurement management, managers are faced with the challenge of either centralizing or decentralizing the procurement activities. According to him, in certain organizations, the procurement function is a distinctive department, while in others, it is found as a unit in materials management department.

In the former, the procurement managers have the responsibility to harness all procurement activities starting from material requisitions to receiving of items. However, the responsibilities of the procurement officers are limited when placed within the materials management unit. In his own view, McNamee (1999) believes that integrating procurement activities within the general material management function will allow the procurement officers to concentrate on the specific functions of procurement instead of being overwhelmed by large span of controls and activities. He maintains that the main argument would rather be to either centralize purchasing activities or decentralize them. Each of the options, according to him, has inherent advantages and disadvantages. Chanda (2003) states that every organization has a set of operating rules and procedures that serves as a guide for standards. These guidelines are set for employee to lead them to higher level of performance. The procedures and law involves collecting information and evaluating it, which is a useful process for managers to make decision and provide solutions to problems arising from the organizational structure.

A management system or structure well put in place helps managers in achieving the objectives of the organization, if the structure is appropriately coordinated it will enhance flexible decision making, eliminate 
bottlenecks, create new product and business opportunity, which leads to increase in output, revenue for the institution (De Anis and Haggins 2001).

The African Development Bank's procurement unit prior to the 2008 was in charge of executing procurement policy function. The department that was in charge of procurement activities was divided into two divisions (OPFR1 and 2) to cater for procurement service and financial service. The department was later upgraded to cover fiduciary services for operations, project preparations, appraisal, launching and supervision, preparing strategic country reports. Other activities include reviews of procurement documents, setting the rules for recruitment of consultants or outsourcing projects, planning and early assessment of the borrower's capacity, and the monitoring and evaluation of projects. (AFDB,2014).

\section{Influence of Quality Management Systems on Institutional Procurement Performance}

Quality, according to McClain and Thomas (1980) refers to how well outputs conforms to the aspirations and expectations of consumers. By this definition, it is imperative that quality has many dimensions, especially in human service area, where the concept of need is subjective and elusive. The dimensions of quality include reliability and consistency. Reliability is an important dimension of quality. If a system or machine does what it is designed to do, and maintains standard quality; quantity and cost, the system or machine may be referred to as a reliable system or machine (Buffa, 1997).

A second dimension of quality is consistency. Consistency is valued by consumers regardless of the average quality level. Inconsistency can lead to loss of image or reputation, and of cause to a loss of customers (McClain and Thomas, 1980). Studies (Baridam, 1990; Boyan, 2003; and Armstrong, 2001) have a consensus on what good quality control is. According to these studies, quality control takes a periodic inspection format, getting response from the market through adjustments and correspondence from clients. The procurement management office needs to work together from the need identification stage to the receiving stage. In this case, efforts are made to ensure that adequate assistance is provided to all parties in the supply chain network. Another study by Berger \& Humphrey (2007) states that quality management system can be broken down into four components which are: assurance, planning, quality control and improvement. This means to achieve best performance, the management team must put together the above outline points into a system so as to maintain their customers. Quality products and timely delivery builds trust and organizations survival depends on that. Organizations must therefore provide the procurement practitioner all the tools and motivation needed to deliver quality goods and services.

Africa in recent times has greatly improved the quality of product and services offered to consumers. This is because of the improvement partly done in process of recruiting, the structure put in place for management and institutional regulations that has successfully guided this process (Zeinthaml.2000). Armstrong (2001) stated that an important procurement management function is to motivate workers by encouraging them to performing their duties. He further stated that motivation was so important as the level of motivation is directly proportionate to performance. Also looking at the work environment, it was clear that a positive work environment naturally influence performance. in addition, it is stated that positive work environment reduces complaint and grievance, frequent absenteeism from work, and termination of contract. On the other hand, it improves quality and quantity of production, creates healthier workforce and quality of life of the workers. These factors as stated by Armstrong (2001) have been found to create a correlation between motivated and delighted staff which serves as a prerequisite for satisfying the customers. 


$$
\begin{array}{r}
\text { Vol.8 No.3, pp.50-73, August } 2020 \\
\text { Published by ECRTD UK }
\end{array}
$$

ISSN 2054-0930 (Print), ISSN 2054-0949 (Online)

\section{Influence of Information Technology (IT) on Institutional Procurement Performance}

Campbell (2005), posits that changing or integrating the means of processing or producing goods and service from one version to a better one using scientific methods is known as technology. This is also the changing of operational inefficient method which involves manual processing to automatic operation. E-procurement and E-tendering have taken the place of local order system and has turn the world into a global market place whereby putting the consumer and manufacturer on a common platform to bargain on cost, quality and delivery (Njiforti, 2014). The advent of information communication technology (ICT) has changed both public and private sector business operation. Many organizations have now resulted in increasing use or technology to bring down total cost of acquiring a service or product. E-procurement has gain popularity to this effect as it is used by both the government and private organizations.

Internet technology which is relatively cheap and flexible to use has led to a significant drift from the ordinary ways of doing things in the business environment. It is the worth nothing that technology which is just a tool used by organizations in sourcing and procurement related activities has gain significant place in the hearts of all business firms. Since the 1990s information communication technology has been a decisive determinant in the progressive growth and performance on companies. Technologies have not only become relatively cheap and flexible nowadays, but have developed interconnectivity between units of an enterprise. (Monrove, 2002).

Rusek (2006), in his work states that technology has offered more opportunities for organizations through the digitalization of data and information which provides the opportunity for improved efficiency in the administrative processes for both public and private sectors procuring units. This provides a number of advantages such as establishing new and more efficient work processes. It also reduces the traditional paperbased procurement activities. This will definitely reduce cost and increase profit margin in administrative services. It increases speed and efficiency in procurement performance of the organization. Rusek (2006) also looks at the negative side of information technology. He states that digital information can easily be stolen, deleted without a trace or changed. This therefore requires security and comprehensive training and retraining of procurement employees to keep abreast with the trend in technology. The number of bidders has significantly increases in recent times which have been as a result of an increase awareness of Eprocurement and information technology big organization such as the African Development Bank. The Implementation of E-procurement has been limited by many factors in both the private and public organizations. These ranges from high maintenance cost, cost of equipment and professionalism level required.

Berger and Humphrey (2007) also stated that it has been difficult to absorb the concept of e-procurement in Africa and very few countries are making efforts to improve. A good example is Kenya that has taken measures to improve on public procurement by putting for policies to drive this aspect to become competitive. They noted that there are already systems in place like the reverse auction which is meant to undertake bidding process in procurement. But most procurement firms still carry out manual processes which give lots of room for corruption especially in the public sectors in Africa. This is disadvantageous as it takes longer time to complete a task and increase time lag (Dale 2010). He also stated that most manufacturing companies in Kenya are limited by technological invested which greatly influence efficiency, improve output and eliminate corruption in the system. 
European Journal of Logistics, Purchasing and Supply Chain Management

Vol.8 No.3, pp.50-73, August 2020

Published by ECRTD UK

ISSN 2054-0930 (Print), ISSN 2054-0949 (Online)

\section{RESEARCH METHODOLOGY}

\section{Research Design}

The research work took a descriptive research design. Descriptive research design is justified for it accuracy and precision on who, what and where or how each item was involved with the research. Accordingly, Sekaran (2006) stated that the descriptive research design brings forth the details and importance of each variable used in the research work. The precision allows for the use of statistical tools such as questionnaires, frequencies and percentages and in some cases interviews to describe the event in it exact nature and occurrence. This enables the researcher collect adequate information necessary for generalization. This method described event accurately and in a systematically organized manner (Babbie, 2002). According to Chandran (2004), the research design describes in details the various characteristics of the study population. Kothari and Garg, (2014) states that, the aim of using descriptive design is to collect accurate information from a representative carefully selected to cover the entire population which is in study.

Okwandu (2004) maintains that research designs could be quantitative or qualitative. This research adopted both design in establishing the correlation between independent variables and dependent variable. The independent variables in this study are staff competence, organizational structure, quality management system, and information technology on the one hand and the other hand is procurement performance as the dependent variable.

\section{Target Population}

This population is seen as the total group of people that the research finding will be generalized upon. Locke, Spirdo and Silverman (2007) categorize research population into four; target, accessible, total and sample population. 140 procurement staff of the African Development Bank (AFDB) in Abidjan in 2019 was the target population of this study.

\section{Table 1: Target Population.}

\begin{tabular}{lc}
\hline Name of Division & Population \\
\hline Corporate Human and General Service & 10 \\
Corporate Human and General Service 0 & 9 \\
Corporate Human and General Service 1 & 49 \\
Corporate Human and General Service 2 & 30 \\
Corporate Human and General Service 3 & 42 \\
\hline TOTAL & $\mathbf{1 4 0}$ \\
\hline
\end{tabular}

Source: AFDB (2019).

\section{Sample and Sampling Procedure}

The sample population, according to Creswell (2014) refers to the number of individuals that are going to form the research subjects in a study. 
This population, according to him, is drawn from the total population of the study using appropriate methods to guarantee a fair representation. This study adopted a purposive sampling method. This type of sampling technique refers to the process by which a researcher selects a sample based on the experience or knowledge of the group that is to be sampled.

Mugenda and Mugenda (2013), states that when the study population is less than 10, 000, a sample size of 10 to $30 \%$ is a good representation of the target population. The researcher therefore considered $30 \%$ in this case as proper for the analysis. The sample size for this research therefore was 42employees $(140 \times 0.3=42)$ who are top management, senior staff and consultants directly involved with procurement activities at the African Development Bank in Abidjan. This sample size was drawn from the Department of procurement which is divided into multiple divisions involved with the various procurement practices of the Bank. The sample population constituted only staff members of the African Development Bank in Abidjan, Cote d'Ivoire. All the members of the procurement department were considered a good population frame for this study. The table below contains the various divisions (Corporate Human and General Service) and the number of procurement staff involved.

Table 2 : Sample Size

\begin{tabular}{lcc}
\hline DIVISION & Population & Sample Size \\
\hline Corporate Human and General Service & 10 & 3 \\
Corporate Human and General Service 0 & 9 & 3 \\
Corporate Human and General Service 1 & 49 & 14 \\
Corporate Human and General Service 2 & 30 & 10 \\
Corporate Human and General Service 3 & 42 & 12 \\
\hline TOTAL & $\mathbf{1 4 0}$ & $\mathbf{4 2}$ \\
\hline
\end{tabular}

\section{Source: AfDB (2018)}

\section{Data Collection Method}

In his research methods for social studies Okwandu (2004) maintains that the two principal means of collecting data in a research is the primary and secondary. According to Cooper \& Schindler (2011), there are many methods of data collection which all are directed to getting results from the data collected.

The primary sources of data to be used for this study include focus group discussion and questionnaire to be administered to the members of the research subject. The secondary sources of data to be used include textbooks, journals, magazines and other documented materials in prints and online. In designing the research instrument, simple and straightforward, but relevant questions will be used. The instruments were divided into two sections: personal data section and research data section.

The researcher personally administered the questionnaires with the help of a research assistant drawn from the organization. The personal administration of hard copies provided an opportunity to offer clarifications on issues that was raised by the participants. The completed copies were retrieved after a week interval. 


\section{Validity and Reliability of Research Instrument}

Validity is the degree to which a test actually brings out the credibility of the data. Colin and Wren (2006), states that it is the credibility of the research. Shuttleworth (2008) argues that the entire concept of validity is a scientific experiment that confirms the result of the data that is used in the research. In establishing validity, the researcher made used of different methods of acquiring data which involved person to person interview, various reports documented from the AFDB and other written materials from different scholars as sources of secondary data. The pilot study was carried out that involved a few individuals to fill the questionnaire.

Julie (2005) posits that reliability is the degree of consistency and stability of results gotten from the data tested. It can be seen as the repeatability of findings or the extent of consistency in the presentation of results over time and the accuracy of the data under survey. Joppe (2000) asserts that if the result of the survey can be produced given like conditions, the survey findings are said to be reliable. Lyndsay (2009) opine that, a test is reliable when it gives the same result repeatedly under the same conditions. This was therefore used to confirm the instruments reliability. The study made use of the Cronbach's alpha in conducting the reliability of each scale. Nunally (2001) stated that the value of alpha more than 0.7 shows that the scale is reliable.

\section{Presentation of Data and Analysis.}

The statistical correlation and descriptive methods were adopted in this study. This was used in analysis of the data so as to establish the factors influencing institutional performance at the African Development Bank. The statistical package used for testing the variables was the statistical package for social science (SPSS) version 23. Content analysis was employed to analyze qualitative data while the measurement of central tendency was used to calculate quantitative data. The use of correlation analysis and multiple regressions were put into use in this research. The intention was to accurately present the different degree of the relationship that existed between the variables. At the final analysis, the various results were presented using graphs, tables and charts for easy understanding.

Presentation of the regression Model:

$\mathrm{Y}=\beta 0+\beta 1 \mathrm{X} 1+\beta 2 \mathrm{X} 2+\beta 3 \mathrm{X} 3+\beta 4 \mathrm{X} 4+\varepsilon$

Where $\mathrm{Y}=$ Institutional Procurement Performance

$\beta 0=$ Constant Term

$\beta 1, \beta 2, \beta 3, \beta 4=$ Coefficients.

$\mathrm{X} 1=$ Staff Competence, $\mathrm{X} 2=$ Organizational Structure; $\mathrm{X} 3=$ Quality Management System

$\mathrm{X} 4=$ Information Technology and $\varepsilon=$ Error Term 
European Journal of Logistics, Purchasing and Supply Chain Management

Vol.8 No.3, pp.50-73, August 2020

Published by ECRTD UK

ISSN 2054-0930 (Print), ISSN 2054-0949 (Online)

\section{DATA ANALYSIS AND DISCUSSION}

\section{Influence of Staff Competence on Institutional Procurement}

The table 3 summarizes the opinions of respondents concerning the influence of staff competence on institutional procurement performance. When asked about how employees' skills affect how they handle complex organizational procurement processes, majority $(77.1 \%)$ strongly agree, and $22.9 \%$ agree. None of the respondents were neutral in their opinions neither did any of them disagree or strongly disagree regarding this point.

Concerning whether the provision of adequate professional support by management through training has an impact on procurement performance, the majority (62.9\%) strongly agrees and $37.1 \%$ agree. No respondent was neutral nor did any of them express any form of disagreement. Therefore, generally, all the respondents agree with the fact that the provision of adequate professional support by management through training has an impact on procurement performance.

On whether management positions are occupied by more qualified staff leading to higher performance of the procurement team, 34.3\% strongly agreed, $40 \%$ agreed, $14.3 \%$ expressed a neutral opinion, and $11.4 \%$ strongly disagreed. Finally, about whether employment in the organization is strictly based on experience, $25.7 \%$ were in strong agreement, $40 \%$ agreed, $11.4 \%$ expressed a neutral opinion, $11.4 \%$ strongly disagreed and $11.4 \%$ disagreed. On a general basis, it shows $50 \%$ of the respondents either strongly agree or agree on the fact that employment is strictly based on qualification.

\section{Table 3: Respondents opinion on the Influence of Staff Competence on Institutional Procurement}

\begin{tabular}{lllllll}
\hline Statements & SA & A & N & D & SD \\
\hline $\begin{array}{l}\text { Employees' skills affect how they handle complex } \\
\text { organizational procurement processes }\end{array}$ & $77.1 \%$ & $22.9 \%$ & $0.0 \%$ & $0.0 \%$ & $0.0 \%$ \\
$\begin{array}{l}\text { The provision of adequate professional support by } \\
\text { management through training has an impact on }\end{array}$ & $62.9 \%$ & $37.1 \%$ & $0.0 \%$ & $0.0 \%$ & $0.0 \%$ \\
procurement performance \\
$\begin{array}{l}\text { Management positions are occupied by more qualified } \\
\text { staff leading to higher performance of the procurement }\end{array}$ \\
team
\end{tabular}

\section{Source: Researcher (2019)}

Table 4 shows the regression model of staff competence on institutional procurement performance. The R. square is presented in the table as 0.332 also known as the coefficient of determination. $\mathrm{R}$ is 0.576 at the 0.05 level of significance. From the results it also shows that $31.2 \%$ variation in institutional procurement performance is caused by staff competence. The relationship is positively significant for staff competence and institutional procurement performance. 
European Journal of Logistics, Purchasing and Supply Chain Management

Vol.8 No.3, pp.50-73, August 2020

Published by ECRTD UK

ISSN 2054-0930 (Print), ISSN 2054-0949 (Online)

Table 4: Regression Model Summary

\begin{tabular}{lcccc}
\hline Model & R & R Square & Adjusted R Square & Std. Error of the Estimate \\
\hline 1 & $.576^{\mathrm{a}}$ & .332 & .312 & .34654 \\
\hline
\end{tabular}

Note: "a" is Predictors: (Constant), Staff Competence

Source: Researcher (2019)

The Analysis of variance (ANOVA) results as shown in Table 5 further confirms that the model fit is appropriate for this data since p-value of 0.000 which is less than 0.05 . This implies that there is a significant linear relationship between staff competence and institutional procurement performance.

Table 5: Analysis of Variance (ANOVA) for staff competence

\begin{tabular}{llllll}
\hline Model & Sum of Squares & Df & Mean Square & F & Sig. \\
\hline Regression & 1.969 & 1 & 1.969 & 16.392 & $.000^{\mathrm{b}}$ \\
Residual & 3.963 & 33 & .120 & & \\
\hline Total & $\mathbf{5 . 9 3 1}$ & $\mathbf{3 4}$ & & & \\
\hline
\end{tabular}

a. Dependent Variable: Institutional Procurement Performance

b. Predictors: (Constant), Staff Competence

Source: Field Data (2019)

The table 6 shows the effects of staff competence as a variable in this study shows a positive and significant relationship with the performance of procurement at the AFDB as seen on the table 15 above. The regression model will be given as; $\boldsymbol{y}=\mathbf{0 . 9 8 6}+\mathbf{0 . 4 7 7} \boldsymbol{x}_{\mathbf{1}}$. This therefore indicates that a unit increase in staff competence leads to approximately $48 \%$ ( 0.477 units) increase in institutional procurement performance. The constant value of 0.986 which is an autonomous value shows that without any positive record of competency among staffs, institutional procurement performance remains at 0.986 positive which means that there are other factors that drive institutional procurement performance. These are organizational structure, information technology, and quality management system.

Table 6: Coefficients of Staff Competence

\begin{tabular}{llllll}
\hline Model & \multicolumn{2}{l}{ Unstandardized Coefficients $\begin{array}{l}\text { Standardized } \\
\text { Coefficients }\end{array}$} & T & Sig. \\
\cline { 2 - 5 } & B & Std. Error & Beta & & \\
\hline (Constant) & .986 & .203 & & 4.868 & .000 \\
Staff Competence & .477 & .118 & .576 & 4.049 & .000 \\
\hline
\end{tabular}

Note: Dependent Variable is Institutional Procurement Performance 


\author{
Vol.8 No.3, pp.50-73, August 2020 \\ Published by ECRTD UK
}

ISSN 2054-0930 (Print), ISSN 2054-0949 (Online)

\title{
Influence of Organizational Structure on Institutional Procurement Performance
}

Table 7 summarizes the respondents' opinions on the effect of organizational structure on institutional procurement performance. About whether organizational authority is evenly distributed in various departments, $20 \%$ of the respondents strongly agree that purchasing authority is evenly distributed in various departments, $11.4 \%$ agree that purchasing authority is evenly distributed in various departments, $17.1 \%$ expressed a neutral opinion, $31.4 \%$ strongly disagreed and $20 \%$ disagreed that organizational purchasing authority is evenly distributed in various departments. Looking at the above results, it is evident that organizational purchasing authority is not evenly distributed in various departments.

Concerning whether stakeholders are involved in setting and achieving organizational goals and objectives, majority of the respondents $(77.1 \%)$ strongly agreed, $20 \%$ agreed and $2.9 \%$ strongly disagreed that stakeholders are involved in setting and achieving organizational objectives. None of the respondents expressed a neutral opinion and none disagreed on the matter. With the analysis above therefore, it can be concluded that stakeholders are involved in the setting and achievement of organizational objectives. Seeking to find out whether the organization involves key stakeholders in decision making, $42.9 \%$ of the respondents strongly agreed and $57.1 \%$ agreed that key stakeholders get involved in decision making. There was no respondent who expressed neutral opinion, nor was there any who strongly disagreed or disagreed. This becomes very clear therefore that the organization involves key stakeholders in decision making.

Furthermore, about whether the organization aligns roles with specific tasks and responsibilities, 40\% strongly agreed, 51.4\% agreed, and $8.6 \%$ expressed neutral opinion. None of the respondents strongly disagreed or disagreed. Therefore, one can be accurate to conclude that the organization aligns roles with specific tasks and responsibilities.

Finally, when enquiring about whether activities and performance are evaluated periodically in their organizations, $48.6 \%$ strongly agreed that activities and performances are evaluated periodically, and $51.4 \%$ agreed to the statement. Therefore, we can conclude that in the organization, activities and performance are periodically evaluated.

Table 7: Respondents' opinion on Influence organizational structure on Institutional Performance

\begin{tabular}{|c|c|c|c|c|}
\hline Statement & $\mathbf{A}$ & $\mathbf{N}$ & D & SD \\
\hline $\begin{array}{l}\text { Organizational purchasing authority is evenly distributed } \\
\text { in various departments }\end{array}$ & $11.4 \%$ & $17.1 \%$ & $20.0 \%$ & $31.4 \%$ \\
\hline $\begin{array}{l}\text { Stakeholders are involved in setting and achieving } \\
\text { organizational objectives }\end{array}$ & $20.0 \%$ & $0.0 \%$ & $0.0 \%$ & $2.9 \%$ \\
\hline $\begin{array}{l}\text { My organization involves key stakeholders in decision } 42.9 \% \\
\text { making }\end{array}$ & $57.1 \%$ & $0.0 \%$ & $0.0 \%$ & $0.0 \%$ \\
\hline $\begin{array}{l}\text { My organization aligns roles with specific tasks and } 40.0 \% \\
\text { responsibilities }\end{array}$ & $51.4 \%$ & $8.6 \%$ & $0.0 \%$ & $0.0 \%$ \\
\hline $\begin{array}{l}\text { Activities and performance are evaluated periodically in } 48.6 \% \\
\text { my organization }\end{array}$ & $51.4 \%$ & $0.0 \%$ & $0.0 \%$ & $0.0 \%$ \\
\hline
\end{tabular}

Source: Field Data (2019) 
European Journal of Logistics, Purchasing and Supply Chain Management

$$
\begin{array}{r}
\text { Vol.8 No.3, pp.50-73, August } 2020 \\
\text { Published by ECRTD UK }
\end{array}
$$

ISSN 2054-0930 (Print), ISSN 2054-0949 (Online)

Table 8 presents the regression model of Organizational Structure and Institutional Procurement Performance. All things being equal, the table shows that R square is 0.193 and $\mathrm{R}$ stands at 0.49 and at $1 \%$ level of significance. From the above result, $16.9 \%$ of the variation as indicated in procurement performance is caused by organizational structure. From the above analysis, it was concluded that there exists a positive relationship between procurement performance and organizational structure.

Table 8: Regression Model Summary

\begin{tabular}{lccccc}
\hline Model & R & R Square & Adjusted & R Square & Std. Error of the Estimate \\
\hline 1 & $.439^{\text {a }}$ & .193 & .169 & .38085 \\
\hline
\end{tabular}

a. Predictors: (Constant), Organizational Structure

Source: Field Data (2019)

Table 9 presents the regression model of Organizational Structure and Institutional Procurement Performance. All things being equal, the table shows that R square is 0.193 and $\mathrm{R}$ stands at 0.49 and at $1 \%$ level of significance. From the above result, $16.9 \%$ of the variation as indicated in procurement performance is caused by organizational structure. From the above analysis, it was concluded that there exists a positive relationship between procurement performance and organizational structure.

Table 9: Analysis of Variance (ANOVA) on Organizational Structure and Institutional Procurement Performance

\begin{tabular}{llllll}
\hline Model & Sum of Squares & df & Mean Square & F & Sig. \\
\hline Regression & 1.145 & 1 & 1.145 & 7.893 & $.008^{\mathrm{b}}$ \\
Residual & 4.787 & 33 & .145 & & \\
\hline & Total & 5.931 & 34 & & \\
\hline
\end{tabular}

a. Dependent Variable: Institutional Procurement Performance

b. Predictors: (Constant), Organizational Structure

Source: Field Data (2019)

The results of ANOVA shown in the table 9 above, is a confirmation that the data was appropriate for the analysis. The p-value 0.008 which is less than 0.05 was an indication of a strong positive relationship that exists between organizational structure and procurement performance.

Table 10: Coefficients of Organizational Structure and Institutional Procurement Performance

\begin{tabular}{llllll}
\hline Model & \multicolumn{2}{l}{$\begin{array}{l}\text { Unstandardized } \\
\text { Coefficients }\end{array}$} & $\begin{array}{l}\text { Standardized } \\
\text { Coefficients }\end{array}$ & T & Sig. \\
\cline { 2 - 5 } & $\mathrm{B}$ & Std. Error & Beta & & \\
\hline (Constant) & .830 & .341 & & 2.432 & .021 \\
Organizational Structure & .509 & .181 & .439 & 2.809 & .008 \\
\hline
\end{tabular}

a. Dependent Variable: Institutional Procurement Performance

Source: Field Data (2019) 
From all indications, there exist a positive relationship as shown in Table 10 above between organizational structure and institutional procurement performance. The model of fit is $\boldsymbol{y}=\mathbf{0 . 8 3}+\mathbf{0 . 5 0 9 x _ { 2 }}$, implying that any unit change in organizational structure will significantly increase and influence institutional procurement performance by approximately $51 \%$ ( 0.509 unit). Result further showed that in the absence of organizational structure, other factors or variables were responsible for an autonomous or a positive institutional procurement performance of 0.83 . These variables are information technology, staff competence and quality management system.

\section{Influence of Quality Management System on Institutional Procurement Performance}

The table 11 shows the Respondents' opinion on how quality management system affects Institutional procurement performance.

Table 11: Respondents' opinion on quality management system

\begin{tabular}{|c|c|c|c|c|}
\hline Statements & $\mathbf{A}$ & $\mathbf{N}$ & $\mathbf{D}$ & SD \\
\hline $\begin{array}{l}\text { Budgets authorization affects } \text { procurement }_{45.7 \%} \\
\text { performance }\end{array}$ & $48.6 \%$ & $5.7 \%$ & $0.0 \%$ & $0.0 \%$ \\
\hline $\begin{array}{l}\text { Quality management also brings consistency in quality } \\
\text { and a reduction in cost }\end{array}$ & $54.3 \%$ & $11.4 \%$ & $0.0 \%$ & $2.9 \%$ \\
\hline Resource allocation affects procurement performance $54.3 \%$ & $45.7 \%$ & $0.0 \%$ & $0.0 \%$ & $0.0 \%$ \\
\hline $\begin{array}{l}\text { Delay in budget approval leads to delay in delivery of } 77.1 \% \\
\text { key tasks }\end{array}$ & $14.3 \%$ & $8.6 \%$ & $0.0 \%$ & $0.0 \%$ \\
\hline $\begin{array}{l}\text { Strategic planning from management leads to higher } \\
\text { performance by procurement staff }\end{array}$ & $20.0 \%$ & $0.0 \%$ & $0.0 \%$ & $0.0 \%$ \\
\hline
\end{tabular}

\section{Source: Field Data (2019)}

Table 11 above has presented the opinions of respondents as a result of the test regarding the influence of quality management system on institutional procurement performance.

Seeking to know whether budgets authorization affects procurement performance, $45.7 \%$ of the respondents strongly agree, $48.6 \%$ agree and $5.7 \%$ expressed a neutral opinion. None of the respondents strongly disagreed or disagreed. The conclusion therefore is that budgets and authorization affects procurement performance. When asked whether Quality management also brings consistency in quality and a reduction in cost, $31.4 \%$ strongly agree, $54.3 \%$ agree, $11.4 \%$ were neutral and $2.9 \%$ strongly disagreed. None of the respondents disagreed. Generally, a majority of the respondents agree that quality management also brings consistency in quality and a reduction in cost.

About resource allocation and procurement performance, $54.3 \%$ strongly agreed and $45.7 \%$ agreed that resource allocation affects procurement performance, no respondent expressed a neutral opinion and none strongly disagreed or disagreed. With the above results, it is ok to conclude that resource allocation affects procurement performance. Enquiring about whether delay in budget approval leads to delay in delivery of key tasks, $77.1 \%$ of the research subjects under review strongly agreed $14.3 \%$ agreed and $8.6 \%$ expressed 
neutrality. No respondent strongly disagreed or disagreed on this enquiry. It is therefore clear that when there is a delay in budget approval there will be delays in delivery of key tasks.

Finally, on whether strategic planning from management leads to higher performance by procurement staff, $80 \%$ strongly agree and $20 \%$ agree that strategic planning from management leads to higher performance by procurement staff. There was no respondent who expressed a neutral opinion, none who strongly disagreed and none who disagreed. It is therefore very clear that strategic planning from management leads to higher performance by procurement staff.

\section{Table 12: Regression Model Summary}

\begin{tabular}{llll}
\hline R & R Square & Adjusted R Square & Std. Error of the Estimate \\
\hline .001 & -.029 & .424 \\
\hline
\end{tabular}

Note: The independent variable is Quality Management System.

Table 12 shows that the $\mathrm{R}$ square (coefficient of determinant) is 0.001 and $\mathrm{R}$ is 0.029 at the 0.05 significance. The table is a presentation of the regression model of Quality management system on Institutional procurement performance. As indicated by the coefficient of determination, it is clear that a variation of $2.9 \%$ on the institutional procurement performance is influenced by quality management system. This is an indication that there is a negative and insignificant relationship between quality management and institutional procurement performance at the African Development Bank.

\section{Table 13: Analysis of variance (ANOVA) for Quality Management System}

\begin{tabular}{llllll}
\hline & Sum of Squares & Df & Mean Square & F & Sig. \\
\hline Regression & .005 & 1 & .005 & .028 & .868 \\
Residual & 5.926 & 33 & .180 & & \\
\hline Total & 5.931 & 34 & & & \\
\hline
\end{tabular}

The independent variable is Quality Management System.

\section{Source: Field Data (2019)}

The ANOVA (Analysis of Variance) results in the above Table 13 is a confirmation of the model of fit that shows that it is inappropriate for the data collected because the p-value of 0.868 is greater than 0.05 . It is an indication that an insignificant negative relationship exists between Quality Management system and procurement performance. 
European Journal of Logistics, Purchasing and Supply Chain Management

Vol.8 No.3, pp.50-73, August 2020

Published by ECRTD UK

ISSN 2054-0930 (Print), ISSN 2054-0949 (Online)

Table 14: Coefficients of Quality Management System and Institutional Procurement Performance

\begin{tabular}{|c|c|c|c|c|c|}
\hline & & $\begin{array}{l}\text { Unstandardized } \\
\text { Coefficients }\end{array}$ & \multirow{2}{*}{$\begin{array}{l}\text { Standardized } \\
\text { Coefficients } \\
\text { Beta }\end{array}$} & \multirow[t]{2}{*}{$\mathbf{T}$} & \multirow[t]{2}{*}{ Sig. } \\
\hline & $\mathrm{B}$ & Std. Error & & & \\
\hline $\begin{array}{l}\text { Quality } \\
\text { System }\end{array}$ & Management -.033 & .195 & -.029 & -.167 & .868 \\
\hline (Constant) & 1.820 & .298 & & 6.110 & .000 \\
\hline
\end{tabular}

Source: Field Data (2019)

The outcome further showed that Quality Management System has a negative and insignificant impact on Institutional Procurement Performance (Table 14). The model of fit; $\boldsymbol{y}=\mathbf{1 . 8 2}-\mathbf{0 . 0 3 3} \boldsymbol{x}_{\mathbf{3}}$. This shows that any change in unit of Quality Management System will decrease Institutional Procurement performance by the 0.033 rate. However, in the advent of non-existent of Quality management system, Institutional Procurement Performance becomes positive at 1.820 showing that all things being equal, other factors are responsible for Institutional Procurement Performance which includes staff competence, organizational structure and information technology.

\section{Influence of Information Technology on Institutional Procurement Performance}

The table 15 shows the respondent's opinion on influence of Information Technology on Institutional Procurement Performance

Table 15: Respondents' opinion on Information Technology

\begin{tabular}{lccccc}
\hline Statements & SA & A & N & D & SD \\
\hline $\begin{array}{l}\text { My organization has latest ICT infrastructure to support } \\
\text { procurement }\end{array}$ & $28 \%$ & $28.6 \%$ & $20.0 \%$ & $14.3 \%$ & $28.6 \%$ \\
$\begin{array}{l}\text { My organization has adopted E-Tendering in sourcing of } \\
\text { service }\end{array}$ & & & & \\
My organization has embraced the concept of information & $34.3 \%$ & $65.7 \%$ & $0.0 \%$ & $0.0 \%$ & $0.0 \%$ \\
$\begin{array}{l}\text { sharing with clients } \\
\text { All staff are fully trained in ICT }\end{array}$ & $11.4 \%$ & $85.7 \%$ & $2.9 \%$ & $0.0 \%$ & $0.0 \%$ \\
ICT reduces cost and lead time in my organization & $25.7 \%$ & $74.3 \%$ & $0.0 \%$ & $0.0 \%$ & $0.0 \%$ \\
\hline
\end{tabular}

\section{Source: Field Data (2019)}

About whether the organization has latest ICT infrastructure to support procurement, $8.6 \%$ of the respondents strongly agree, $28.6 \%$ agree, $20 \%$ were neutral $28.6 \%$ strongly disagreed and $14.3 \%$ disagreed. The result above shows that many of the respondents disagree that the organization has latest ICT infrastructure to support procurement. 
European Journal of Logistics, Purchasing and Supply Chain Management

Vol.8 No.3, pp.50-73, August 2020

Published by ECRTD UK

ISSN 2054-0930 (Print), ISSN 2054-0949 (Online)

It is therefore clear that despite the recent improvement in information and communication, the organization yet do not have latest ICT infrastructure to support procurement.

Table 16: Regression Model Summary

\begin{tabular}{llll}
\hline $\mathbf{R}$ & R Square & Adjusted R Square & Std. Error of the Estimate \\
\hline 334 & .111 & .084 & .400 \\
\hline
\end{tabular}

Note: The independent variable is Information Technology.

Table 16 presents the regression model of Information Technology and Institutional Procurement Performance. As indicated in table 21, the coefficient of determination $\mathrm{R}^{2}=0.111$ and $\mathrm{R}=0.334$ at the level of significance of 0.05 .

As shown by the coefficient of determination, $8.4 \%$ of the changes on Institutional Procurement Performance is impacted by Information Technology. By implication it means a positive relationship exist between Information Technology and Institutional Procurement performance.

Table 17: Analysis of variance (ANOVA) for Information Technology

\begin{tabular}{llllll}
\hline & Sum of Squares & df & Mean Square & F & Sig. \\
\hline Regression & .660 & 1 & .660 & 4.135 & .050 \\
Residual & 5.271 & 33 & .160 & & \\
\hline Total & 5.931 & 34 & & & \\
\hline
\end{tabular}

The independent variable is Information Technology.

Source: Field Data (2019)

Table 17 shows the results of the Analysis of variance (ANOVA) that indicates there results as shown in confirms that the positive significant linear relationship between Information Technology and Institutional Procurement Performance, F $(1,33)=4.135, \mathrm{p}=0.050$.

Table 18: Coefficients Information Technology and Institutional Procurement Performance

\begin{tabular}{|c|c|c|c|c|c|}
\hline & \multicolumn{2}{|c|}{$\begin{array}{l}\text { Unstandardized } \\
\text { Coefficients }\end{array}$} & \multirow{2}{*}{$\begin{array}{l}\text { Standardized } \\
\text { Coefficients } \\
\text { Beta }\end{array}$} & \multirow[t]{2}{*}{$\mathbf{T}$} & \multirow[t]{2}{*}{ Sig. } \\
\hline & $\mathrm{B}$ & Std. Error & & & \\
\hline Information Technology & 2 & .183 & .334 & 2.033 & .050 \\
\hline (Constant) & 2 & .404 & & 2.384 & .023 \\
\hline
\end{tabular}

Source: Field Data (2019)

In the above results, it shows that there is a positive and insignificant impact of Information Technology on Institutional Procurement Performance (Table 18). The model of fit; $\boldsymbol{y}=\mathbf{0 . 9 6 2}-\mathbf{0 . 3 7 2} \boldsymbol{x}_{\mathbf{4}}$. this shows that a unit increase in Information Technology will obviously increase the performance of Institutional Procurement at the rate of 0.372 unit. When Information Technology is non-existence, Institutional 
European Journal of Logistics, Purchasing and Supply Chain Management

Vol.8 No.3, pp.50-73, August 2020

Published by ECRTD UK

ISSN 2054-0930 (Print), ISSN 2054-0949 (Online)

Procurement Performance is positive and autonomous at 0.962 showing that other instruments are pushing Institutional Procurement Performance including Staff Competence, Organizational Structure and Quality Management System.

\section{Regression Model summaries for independent variables}

Table 19 shows the Regression model summary for independent variables.

Table 19: Model Summary

\begin{tabular}{|c|c|c|c|c|}
\hline Model & $\mathbf{R}$ & R Square & Adjusted R Square & Std. Error of the Estimate \\
\hline 1 & $.673^{\mathrm{a}}$ & .453 & .380 & .32875 \\
\hline
\end{tabular}

Source: Field Data (2019)

The model $\boldsymbol{y}=\boldsymbol{\beta}_{\mathbf{0}}+\boldsymbol{\beta}_{\mathbf{1}} \boldsymbol{x}_{\mathbf{1}}+\boldsymbol{\beta}_{\mathbf{2}} \boldsymbol{x}_{\mathbf{2}}+\boldsymbol{\beta}_{\mathbf{3}} \boldsymbol{x}_{\mathbf{3}}+\boldsymbol{\beta}_{\mathbf{4}} \boldsymbol{x}_{\mathbf{4}}+\boldsymbol{\varepsilon}$ explained $38.0 \% \quad$ of the variations in Institutional Procurement Performance as indicated in Table 19. This indicates that staff competence, organizational structure, quality management system and information technology overall explained $38.0 \%$ of the variation in institutional procurement performance.

Table 20: Analysis of Variance (ANOVA)

\begin{tabular}{lccccc}
\hline Model & Sum of Squares & Df & Mean Square & F & Sig. \\
\hline Regression & 2.689 & 4 & .672 & 6.220 & $.001^{\mathrm{b}}$ \\
Residual & 3.242 & 30 & .108 & & \\
\hline Total & 5.931 & 34 & & & \\
\hline
\end{tabular}

a. Dependent Variable: Institutional Procurement Performance

b. Predictors: (Constant), Information Technology, Quality Management System, Organizational Structure, Staff Competence

Source: Field Data (2019)

The analysis of variance results in Table 20 indicates that the model fit is significant at $\mathrm{p}=0.001, \mathrm{~F}=6.220$ with 30 degrees of freedom. This implies that staff competence, organizational structure, quality management system and information technology has a significant and positive combined effect on institutional procurement performance. Research finding as shown in table 20, indicates that the independent variables staff competence, Organization structure, Quality management system and Information Technology significantly influence the institutional procurement performance, $F(4,34)=6.22, p=0.001, R^{2}=0.453$ 
European Journal of Logistics, Purchasing and Supply Chain Management

Vol.8 No.3, pp.50-73, August 2020

Published by ECRTD UK

ISSN 2054-0930 (Print), ISSN 2054-0949 (Online)

Table 21: Coefficients' Relationship between the independent variables and Institutional procurement performance

\begin{tabular}{llllll}
\hline Model & \multicolumn{2}{c}{ Unstandardized Coefficients Standardized } & t & Sig. \\
& \multicolumn{4}{c}{ Coefficients } \\
\cline { 2 - 5 } & $\mathbf{B}$ & Std. Error & Beta & \\
\hline (Constant) & .885 & .471 & & 1.877 & .070 \\
Staff Competence & .500 & .158 & .603 & 3.171 & .003 \\
Organizational Structure & .138 & .197 & .119 & .700 & .489 \\
Quality Management System & -.346 & .172 & -.309 & -2.015 & .053 \\
Information Technology & .148 & .159 & .133 & .930 & .360 \\
\hline
\end{tabular}

a. Dependent Variable: Institutional Procurement Performance

\section{Source: Field Data (2019)}

Presentation of the regression Model:

$\mathrm{Y}=\beta 0+\beta 1 \mathrm{X} 1+\beta 2 \mathrm{X} 2+\beta 3 \mathrm{X} 3+\beta 4 \mathrm{X} 4+\varepsilon$

Where $\mathrm{Y}=$ Institutional Procurement Performance

$\beta 0=$ Constant Term $\beta 1, \beta 2, \beta 3, \beta 4=$ Coefficients

$\mathrm{X} 1=$ Staff Competence, $\mathrm{X} 2=$ Organizational Structure; X3= Quality Management System; X4= Information Technology and $\varepsilon=$ Error Term

$\beta 0=0.885 ; \beta 1=0.500, \beta 2=0.138, \beta 3=-0.346$ and $\beta 4=0.148$.

Hence the general regression model was $y=0.885+5 x_{1}+0.138 x_{2}-0.346 x_{3}+0.148 x_{4}+\varepsilon$

\subsection{Summary of the findings.}

The study sought to investigate the determinants of the institutional procurement performance at the African Development Bank. In achieving the specific objectives of this study, the researcher investigated the ability of staff members to deliver, the processes and procedure of the organization, the system of management and the level of technological awareness and implementation on procurement activities and performance at African Development Bank.

The research work made use of both quantitative and qualitative statistical descriptive analysis. Structured questionnaire was administered by the researcher to gather both quantitative and qualitative information. The target population was 140 employees of the African Development Bank. 42 questionnaires were sent out, however, only 35 returned giving us a response rate of approximately $83.4 \%$.

In testing the variables, independent on the dependent (procurement performance), a multiple regression analysis was used. This was to ascertain the level of influence of staff competence; organizational structure; 
information technology and quality management system on institutional procurement performance. All the determinants significantly showed a relationship with institutional procurement performance. $\left(r^{2}=0.453\right)$. The result of the Pearson Correlation proved that two of the determinants had insignificant influence on institutional procurement performance and two had very significant influence on institutional procurement performance. Quality management system had a negative and insignificant influence and information technology had a positive but insignificant impact of institutional procurement performance. Both staff competence and organizational structure have positive and significant (5\% level) on institutional procurement performance. Among the two variables significantly influencing institutional procurement performance, staff competence takes the lead with a coefficient of 0.394 while organizational structure follows with 0.348 .

Following the findings of this study, one can conclude that internally, not all variables selected for the study have significant influence on institutional procurement performance and more attention should be focused on staff competence and organizational structure in order to improve on institutional procurement performance.

\section{CONCLUSION}

The objective of this study was to assess the determinants of institutional procurement performance with the African Development Bank as our lab rat. Staff competence, organizational structure, quality management system and information system were used as the independent variables. Data analyzed indicated that out of the variables used as predictors, three of them influenced institutional procurement performance positively though the influence of one (information technology) was insignificant. The other variable (quality management system) related negatively with institutional procurement performance and was insignificant too.

The study therefore concludes that if the organization seeks to increase the performance of the procurement team, management needs to pay more and adequate attention to staff competence and organizational structure. Training and retraining of staff in procurement will greatly influence and contribute to productivity of the institution (Appiah 2010). Human capital improvement has been identified from this study as a necessity for optimal procurement performance at the African Development Bank. The role of operation activities were under the borrower's procurement oversight prior to 2008when Procurement Unit was upgraded to a Department (ORPF), with two sections namely Procurement Services Division (ORPF.1) and Financial Management Division (ORPF.2). This study finds it convenient to believe that this is one of the reasons why there is improvement in the procurement performance of the African Development Bank.

\section{Recommendations}

The researcher recommends that other researcher should consider other factors that could influence the Institutional procurement performance and also consider other industry apart from banking industry. Other researchers may adopt a different research design in assessing the influence of institutional procurement performance in other industries 
European Journal of Logistics, Purchasing and Supply Chain Management

Vol.8 No.3, pp.50-73, August 2020

Published by ECRTD UK

ISSN 2054-0930 (Print), ISSN 2054-0949 (Online)

\section{References}

African Development Bank (2014) Review of ADB's procurement policy, procedures and processes Policy framework paper

Ahsan, K. and Rahman, S. (2017). Green public procurement implementation challenges in Australian public healthcare sector, Journal of Cleaner Production, vol. 152, pp. 181-197.

Baridam, D. M. (1999).Management and organizational Theory. Port Harcomt: Sherebrooke Associates

Berger, E. \& Humphrey, N. (2007).Simple Buying Methods. (1st. Ed.), Nairobi: East Africa Education Publishers.

Campbell, J. (2005). Management Concept and Strategies.USA: University of Michigan

Chang, C.W., Chiang, D. M., \&Pai, F.Y.(2012). Cooperative strategy in supply chain networks; Industrial Marketing Management, 41(7), 1114-1124

Chicksand, D., Watson, G., Walker, H., Radnor, Z., \& Johnston, R. (2012). Theoretical perspectives in purchasing and supply chain management: an analysis of the literature. Supply Chain Management: An International Journal, 17(4), 454-472.

Choi, Y., \& Zhang, N. (2011).Assessing the sustainability performance of Chinese industrial Sector.African Journal of Business Management, 5(13), 5261-5270.

Chong, A.Y.L. and Ooi, K.B. (2008).Adoption of inter organizational system standards in supply chains: an empirical analysis of Rosetta Net standards, Industrial Managementand Data Systems, 108 (4), 529547

Cooper D.R., Schindler P.S (2011) Business Research Methods. McGraw-Hill/Irwin,

Creswell, J.W. (2013). Research design: Qualitative, Quantitative, and mixed methods Approaches, $\left(4^{\text {th }}\right.$ Edition.), London: Sage Publications.

Cronbach, L. J. (1971). Test validation. In R. L. Thorndike.EducationalMeasurement (2nd Edition). Washington, D. C.: American Council on Education

Dale, K. (2010). Measuring Service Quality.( ${ }^{\text {st }}$ Edition) London: Pitman Publicatiion

Gompers, Paul A., Joy L. Ishii, and Andrew Metrick (2013).Corporate Governance and Equity Prices.Quarterly Journal of Economics 118(1):107-155.

Green, K.W. Jr, Inman, R.A., Brown, G., Willis, T.H. (2000).Market orientation relation to structure and performance, Journal of Business and Industrial Marketing, 20 (6), 276-84

Gupta, M. C., and Narasimham, S. V. (1998). Discussion of 'CSFs in competitive tendering and negotiation model for BOT projects' Journal for Construction Engineering Management, 124(5), 430

Harland, C. M., \& Knight, L. A. (2001).Supply network strategy: role and competence requirements. International Journal of Operations \& Production Management, 21(4), 476-489

Locke, L. F., Spirduso, W. W., \& Silverman, S. J. (2007).Proposals that work: A guide for planning dissertations and grant proposals. ( ${ }^{\text {th }}$ Edition). Thousand Oaks, CA: Sage 
European Journal of Logistics, Purchasing and Supply Chain Management

Vol.8 No.3, pp.50-73, August 2020

Published by ECRTD UK

ISSN 2054-0930 (Print), ISSN 2054-0949 (Online)

Marshall, C. \& Rossman, G. B. (2006).Designing qualitative research ( $4^{\text {th }}$ Edition.). Thousand Oaks, CA: Sage.

Mugenda, O.M. and Mugenda, A.G. (2013): Research Methods: Quantitative \& Qualitative Approaches. Nairobi: ACTS Press.

Neuhaus, Klaus, Alexander Schmitz, and Tobias Umbeck (2014).Building a World-Class Global Procurement Organization, (accessed January 16, 2016), [available athttp://www.baincom/publications/articles/building-a-world-class-globalprocurementorganization.aspx].

Ngina, E. K (2013).Procurement Performance Measurement in Commercial Banks in Kenya. Unpublished Thesis, University of Nairobi

Nunnally, J. C., \& Bernstein, I.H. (2001).Psychometric Theory, (3 ${ }^{\text {rd }}$ Edition). New York: McGraw Hill.

Nyakundi, E., Kombo, C., Omari, R., Mongare, O. (2012). Challenges Facing Procurement Committees in Implementing the Procurement Act; A Case Study of Secondary Schools Procurement Committees in Kisii County, Kenya. Elixir International Journal 9186-9191

Ondigi, S. K., \&Muturi, W. (2015). Factors Affecting Public Procurement of Hospital Supplies in Public Health Institutions in Kenya: A Case Study of Kisii Teaching and Referral Hospital, Kenya. International Journal of Economics, Commerce and Management, 3(11), 863-872.

Public Procurement Oversight Authority.(2009). Procurement Manual: http://www.ppoa.ac.ke.

Rogers, E.M. (2003). Diffusion of Innovations ( $5^{\text {th }}$ Edition). New York: Free Press.

Rusek, J. M. (2006). Procurement Reforms in Kenya, (1 ${ }^{\text {st }}$ Edition). Nairobi: A Publication of NonGovernmental Organizations

Shuttleworth, M. (2008).How to choose between different research methods.Experiment Resources. Available at: http://www.experiment-resources.com/different-research-methods.html

Thai, K. V. (2010). Towards New Horizons in Public Procurement. Towards Horizons in Public Procurement Pr Press

Thorelli, H.B. (1986). Networks: Between markets and Hierarchies. Strategic Management Journal, 7(3751)

Thumbi, I, M. \&Mutiso, J. M (2018). Influence of procurement process audit on procurement performance in public health facilities in Kiambu County, Kenya. International Journal of Social Sciences and Information Technology, 4(10)404-41 
European Journal of Logistics, Purchasing and Supply Chain Management Vol.8 No.3, pp.50-73, August 2020 Published by ECRTD UK ISSN 2054-0930 (Print), ISSN 2054-0949 (Online) 